\title{
Radicalization and Terrorism: Research within the Australian Context
}

\author{
Riyad Hosain Rahimullah ${ }^{1, *}$, Stephen Larmar ${ }^{1}$ and Mohamad Abdalla ${ }^{2}$ \\ ${ }^{1}$ School of Human Services and Social Work, Griffith University, Australia \\ ${ }^{2}$ School of Humanities, Griffith University, Australia
}

\begin{abstract}
Terrorism perpetrated by some Muslims has become a global phenomenon that has significantly impacted many nations. In the post-September 11 era, Australia has experienced threat of terrorist attacks from organisations including Al-Qaeda and Jemaah Islamiah. In response to this phenomenon the Australian government has heightened security measures and engaged various strategies to counter-radicalization. While the growing body of global research focussing on radicalization and terrorism may inform such strategies, research within the Australian context would provide a cogent platform for assisting in the response to terrorism at a national level. This paper provides discussion focussing on the paucity in literature on the question of radicalization and terrorism. Furthermore, significant gaps in the literature are highlighted and future research recommendations are suggested that would assist in broadening current understanding of the processes of radicalization and terrorism.
\end{abstract}

Keywords: Terrorism, radicalization, Australia, Muslim, Islamic.

Radicalisation and terrorism are not phenomena specific to any one group of people. Various groups, including religious and political bodies have demonstrated radical extremism in the past; for example, Spain's ETA (a nationalist group), Ireland's IRA (a Catholic organisation), the KKK (an American white supremacist group), Sri Lanka's Tamil Tigers (a nationalist entity), and Sinhala Buddhist groups. However, the focus of this paper will centre upon the radicalisation of Muslims within the Australian context.

Since September 11, 2001 acts of terrorism by a small number of Muslims have exacerbated the worldwide focus and concern toward Muslim terrorism and its concomitant ideology, especially amongst the many nations threatened by this phenomenon. Terrorism is usually preluded by radicalization; the process of gradually subscribing to a violent ideology espousing terrorism. This paper will conceptualize radicalization and terrorism as drawn from the literature. The paper will signpost radicalization studies conducted in Australia with terrorist cases and within the general Muslim community. While the studies are few in number, and in part have drawn repeatedly from the same population of terrorist cases, their relevance to the Australian context, as well as the broader research agenda focussing on radicalization is significant. The paper also serves to highlight gaps in current research and knowledge about radicalization as a means of assisting future research, policy development and strategies focussing on de-

*Address correspondence to this author at the School of Human Services and Social Work, Griffith University, Australia; Tel: (61) 733821201 ;

Fax: (61) 7 33821210; E-mail: riyad.rahimullah@griffithuni.edu.au radicalization initiatives as well as preventative programs that reduce the incidence of radicalized behaviours.

Outside Australia, research on radicalization and terrorism has been conducted employing various techniques. For example research has been conducted with terrorist biographical data (e.g. Bakker 2006, Petter 2004), interviews with terrorists (e.g. Horgan 2005), interviews with groups supporting violent extremism in Europe (e.g. Neumann et al. 2007), comparison studies between pro-democratic Muslims and radical Muslims (Buijs, Demant and Hamdy 2006), and research conducted with the general Muslim populations (e.g. Change Institute 2008).

However, the context of other Western countries differ to Australia necessitating research within the Australian context. For example there has been no terrorist attacks on Australian soil to date, although there was one offshore incident in Bali, Indonesia that seriously affected a number of Australian tourists. This has concomitant implications on the socio-political atmosphere of Australia and its people. Australia's strict border security and geographical placing including its oceanic borders make it difficult for external terrorist cells to infiltrate Australia therefore meaning that Australian terrorists need to be 'homegrown'. Finally Australia plays a lesser political role in the West's relationship with the Muslim world making Australia a lower priority target of terrorism. Despite these seemingly protective elements of the Australian context, homegrown terrorism in Australia is a fact with at least 36 known cases of Muslim terrorism (Mullins 2011). This raises questions as to why 
radicalization might occur in the Australian context given its difference to other more targeted nations. Hence there is a need to conduct research in Australia to answer this question.

The ideology of contemporary terrorism also deserves some discussion to frame why it would be perpetrated in the West. Firstly, there is an ideological divide between terrorist groups on this issue. The motives of those who carry out terrorism in the West range from retaliation for Western military presence in Saudi Arabia (Schwartz 2007), to a nation's involvement in killing Muslims in the war in Iraq (Ramakrishna 2005). This contrasts with terrorism in a Muslim country which is done in order to gain independence from corrupt, oppressive and authoritarian regimes (Hassan 2008).

Contemporary Muslim terrorist ideology finds its roots in interpreting the writings of certain controversial Islamic scholars. Such scholars include $20^{\text {th }}$ Century intellectuals such as Syed Qutb (Calvert 2010) Abul A'la Maududi and Abd al-Salam Faraj (Hassan 2008). For example Qutb's (1964) book Milestones, advocated for the Muslims' need to use power to make God sovereign in the world, including both the 'decadent' Western and Muslim worlds. Without being given the opportunity to explicitly promote violence as a result of his execution, interpretations of his works following his demise have founded violent and radical agendas in Egypt and abroad (Calvert 2010). Additionally, it is believed that a distorted fatwa of $14^{\text {th }}$ Century scholar IbnTayimiyyah (whose views influence Abdul Wahhab and the Wahhabi movement) were foundational in inspiring these $20^{\text {th }}$ Century scholars in their radicalist views (Schwartz 2007). This fatwa of Ibn Taymiyyah has undergone scrutiny by a group of 15 leading Islamic scholars who gathered in Mardin in 2010. By referring back to an original manuscript of the fatwa they concluded that two letters of one word were distorted. So instead of being an order to 'fight' those outside Islamic authority as their due, it was actually an admonition to 'treat' such people according to their rights (al-Turayri 2010, Murshed 2011). These are some examples of how terrorist groups have manipulated the writings of scholars to fuel their ideology.

\section{CONCEPTUALISING RADICALIZATION AND TERRORISM}

The term radicalisation is a key term used when discussing trajectories towards committing terrorism.
However it is often utilised in such discourse without being defined. For example NATO provides no definition of radicalism according to their Allied Administrative Publication No. 6 (AAP-6) (2007); their reference document of the Military Committee Terminology Standardization Programme (MCTSP). Further, the term radical and its derivatives are not defined in the Department of Defence's Dictionary of Military Terms (2010) which is the United State's Department of Defence's version of NATO's AAP-6.

Neumann (2008) defines radicalism as 'what goes on before the bombs go off'. However this colloquial definition is extremely limited as it fails to give consideration to the dynamics associated with the period preceding an act of terrorism that would be classified as radicalisation. Several clearer definitions have been proposed. According to the Netherlands' General Intelligence and Security Service report (AVID 2007), radicalism refers to "the active pursuit of and/or support for far-reaching changes in society which may constitute a danger to the continuity of the democratic legal order (aim), possibly by using undemocratic methods (means) which may harm the functioning of that order (effect)" (p. 10). The report goes on to state, "by extension, then, radicalisation is the process of increasing readiness to pursue such changes possibly by undemocratic means - and/or to encourage others to do so" (AVID 2007, p. 20). By contrast, AIVD's definition is more detailed than Neumann's and mainly focuses on political change by undemocratic means.

Mandel (in press) explores at length the meaning of radicalism extracting from lexical and common place usages of the word. Mandel concludes that radicalism is best defined as: "an increase in and/or reinforcing of extremism in the thinking, sentiments, and/or behaviours of individuals and/or groups of individuals." However, this relies upon an agreed upon meaning for the term 'extreme'. Mandel refers to extremism as terrorism. The Danish intelligence services (PET) parallel Mandel's conceptualisation of the term, asserting that radicalisation is 'a process, by which a person to an increasing extent accepts the use of undemocratic or violent means, including terrorism, in an attempt to reach a specific political/ideological objective' (PET, 2009, p. 1, as cited in Veldhuis and Staun 2009). Further, the European Commission defines radicalism as the phenomenon of people embracing opinions, views and ideas which could lead to acts of terrorism' (European Commission 2006). 
For the purposes of this paper, the authors have drawn on key preceding definitions of radicalization in order to develop the following conceptualisation of this phenomenon. Therefore, radicalization can be defined as:

...a process involving an individual or group whereby they are indoctrinated to a set of beliefs that support acts of terrorism that can be manifested in one's behaviour and attitudes.

It is important to note that radicalization does not equate to terrorism. While radicalization typically precedes acts of terrorism (Sageman 2007, June 27, Silber and Bhatt 2007) a radicalized individual may not necessarily intend to commit terrorist activities (Mandel in press) but rather merely be in favour of them. However, some individuals who commit terrorism may circumvent the process of radicalization (Mandel in press). This trend warrants attention in future research.

Since the definition of radicalization frequently utilizes terrorism as a key construct, the term 'terrorism' will also be defined. Unlike radicalization there is greater clarity in contemporary understanding regarding the definition of terrorism. According to the Council of the European Union and for the purposes of this paper, terrorism is defined as:

... intentional acts that are committed with the aim of seriously intimidating a population, or unduly compelling a government or international organisation to perform or abstain from performing any act, or seriously destabilising or destroying the fundamental political, constitutional, economic or social structures of a country or an international organization (European Commission 2006).

\section{TERRORISM AND RADICALIZATION IN AUSTRALIA}

There has been no known terrorist attack by Muslims on Australian soil. However, both al-Qaeda and Jemaah Islamiah have singled out Australia as one of their target nations (Department of Foreigh Affairs and Trade (DFAT) 2004). In recent years however, two terror plots by Muslims have been foiled within the Australian context. Three men were convicted in 2009 for planned attacks on an army base in the city of Sydney, New South Wales (2010b). Similarly, five men were convicted in 2010 for planned attacks on a major football event in the city of Melbourne, Victoria (2010a).
At the time of their arrest, these men were in possession of a substantial amount of terrorist propaganda. Three of these men were involved in terrorist training in New South Wales that served to prepare them for such activity. There was also an offshore terrorist attack in 2002 targeting a Bali night club frequented by Australian tourists. While Jemaah Islamiah claimed responsibility for the attack, Osama bin Laden issued a videotaped recording declaring that the attack served as a retaliatory response to Australia's role in the liberation of East Timor (Parkinson 2002).

There is currently a dearth of academic research concerning the prevalence of radicalization amongst Muslims in Australia. However, a member of the Muslim Community Reference Group (MCRG) that was formed under the Howard Government in 2005, Mustapha Kara-Ali, drafted a report in 2007 about the extent of the problem. He claimed that up to 3000 young Muslims in Sydney were at risk of radicalizing (Crawford 2007) based upon their exposure to radical teachings (Tobin 2007). However, the research findings were questioned because it lacked peer review and was not, therefore, published, rendering the veracity of its findings as doubtful.

In their research with Muslims residing in New South Wales and Victoria in 2007 to 2008, Woodlock and Russell (2008) found that the majority of its 600 participants rejected extremism. They also found that perceptions concerning the prevalence of extremism depended on the individual's religio-political outlook. When asked whether the prevalence of extremism was increasing or decreasing, half the sample perceived it as unchanging.

Porter and Kebbell (2010) conducted analyses on the 21 convicted terrorists in Australia known at the time of their research, nine of which were 25 years old or younger. Several insights can be gained from this research. First, the phenomenon of 'homegrown' terrorism is a reality in Australia. Second, there is no strict psychopathological profile of a terrorist. Third, there is no strict demographic profile that aligns with an individual who engages in terrorist activities. Fourth, transitory religious experiences precede involvement in terrorist activity. Fifth, terrorists seem convinced that their actions are in accordance with Islam. Sixth, they possess altruistic tendencies. Seventh, radicalization does not necessarily occur in a group. And finally, the internet seems to have played a role in radicalization. 
Mullins (2011) studied 36 known Muslim terrorist cases in Australia and developed similar findings with basic elements of Porter and Kebbell's research. However, their research extrapolated the following: the majority were aged between 20 and 30 years of age; resided in Australia for at least 10 years; were not educated beyond high school level; were in semi- or unskilled occupations; were married; had no criminal records prior to their terrorist activities; were not dictated by an international terrorist group (although varying degrees or support was sometimes found) and none were confirmed mentally ill.

Zammit (2011) compared this group with other convicted terrorists from America, the UK and Western Europe and found both similarities and differences across each cohort. The research found that Australian terrorists compare to their counterparts in terms of being young, of low employment status, and being of low religiosity in their youth. However, Australian terrorists contrasted with their overseas counterparts, as they are more likely to be married with children, of predominantly Lebanese background, less educated and born or raised in Australia. Further, Australian terrorists are greater in proportion to the Muslim population than in other Western countries. This could be due to either Australia's smaller overall population, the reality that fewer Muslims reside in Australia than other Western countries, or due to other circumstances specific to the Australian context.

Several concerns should be noted. Studies of radicalisation with the broader Muslim population do not appear to have been published in peer reviewed journals rendering their findings questionable. Additionally, studies with terrorists did not gain direct access to the convicted terrorists who comprised the respective study samples. Hence, although making sophisticated inferences about radicalisation, each study lacked several points of investigation. For example, theories such as moral disengagement, terror management, and uncertainty reduction that have been implicated in radicalization were not applied to the terrorists under investigation. Further, the possible presence of other risk factors was not reported and the cognitive processes (including bias) that led to their ideological conversion was not explored. The studies were also unable to compare the convicted terrorists with a control sample population. This approach would have proved worthwhile to discriminate between shared and isolated factors amongst terrorist and non- terrorist individuals as has been facilitated in research in other Western nations (Bartlett and Miller 2011).

\section{FUTURE RESEARCH IN RADICALIZATION}

This paper has highlighted that little research has been published on the topic of radicalization and terrorism in Australia. Studies of terrorists rely on publically available information that is void of much information potentially important to studying radicalization. Hence such research is also generally restricted to simplified means of data analysis. Further, terrorists are usually products of the full radicalization process and studying these terrorists retrospectively could lead to fallacious reasoning including hindsight bias (Mullins 2011) and poor external validity (Veldhuis and Staun 2009). Therefore, the study of radicalization of non-terrorists is necessary to avoid such fallacies. Further, many other factors may play a role in radicalisation that was not discussed in current research. For example, personal experiences, the influence (or rejection) of culture, lack of integration with society and its associated reasons could all play roles in radicalization. Questions that arise from the paucity of research in the Australian context include: (1) at what age can one radicalize? (2) what differentiates a path to violent radicalization from other political and religious expressions? (Veldhuis and Staun 2009) and (3) what types of pathways to violent radicalization exist in the Australian context?

Future studies must also make greater utilization of empirical methods. For example, employing more cross-sectional research, or more ideally a longitudinal study, of Australian Muslims representative of the entire Muslim community may introduce insights into the radicalization process not yet considered or investigated in depth. Transdisciplinary research (Nasser-Eddine et al. 2011) and qualitative interviews would add breadth and depth of knowledge on issues surrounding radicalization. Comparisons between Muslims involved in the radicalization process, and others who abandon it or reject it (Nasser-Eddine et al.) (or are oblivious to radicalization) will also expand this field of literature. In conjunction with these broader research approaches more sophisticated empirical analyses can be employed that would assist in answering the question of causality of this complex phenomenon. Such analyses might include structured equation modelling, regression and discriminant analysis. Research on radicalization, moreover, must appreciate the impact of external factors on radicalisation. Factors such as Islamophobia (Beutel 
2007), foreign occupation in Muslim lands (Pape 2006), and pejorative media coverage (Nasser-Eddine et al. 2011) of Muslims are known to play important roles in radicalization in other nations. Additionally, Australian government policies, both towards the Muslim world and its national security policies may serve as potential catalysts for radicalization.

\section{CONCLUSION}

Terrorism is an active threat to Australian security and there is a growing concern about individuals following a radicalisation trajectory. This highlights the necessity to study radicalization in the Australian context. In this paper definitions of radicalization and terrorism were examined. A range of Australian studies were summarized, highlighting a number of inherent limitations including methodologies that limited the focus of inquiry to known terrorists and the restrictive reliance on secondary sources for information. A fertile opportunity exists alongside current research on terrorism to investigate the pre-, early and middle phases of the radicalization process as well as nonradicalization pathways in the Australian context. By employing cross-sectional or longitudinal research methods such limitations in the current field within the Australian context can be addressed. The facilitation of empirically based research agendas will assist in the provision of a more comprehensive understanding of the process of radicalization and its impacts upon terrorism in the Australian context. Such research would serve to inform policy development as well as provide cogent methods to counter and prevent radicalization, and de-radicalize individuals and groups.

\section{REFERENCES}

2007. Allied Administrative Publication No. 6Congress.

2010a, "Australian Court Sentences 5 Men in Terrorist Plot": ABCNews. Retrieved 002/02/2011, (http://www.abc.net.au).

2010b, "3 Convicted of Terror Plot on Australian Army Base": The Associate Press, Yahoo. Retrieved 02/02/2011, (my.news.yahoo.com/3-convicted-terror-plot-australian-army20101222-155034-005.html).

Al-Turayri, A. 2010, "The Mardin Conference - Understanding Ibn Taymiyyah's Fatwa". Retrieved 07/07/11, (http://muslimmatters.org/2010/06/29/the-mardin-conference-a-detailed-account/).

AVID, General Intelligence and Security Service. 2007. The Radical Dawa in Transition: The Rise of Islamic Neoradicalism in the Netherlands.

Bakker, Edwin. 2006. "Jihadi Terrorists in Europe: Their Characteristics and the Circumstances in Which They Joined the Jihad: An Exploratory Study." Vol.: Netherlands Institute of International Relations.

Bartlett, Jamie and Carl Miller. 2011. "The Edge of Violence: Towards Telling the Difference between Violent and
Non-Violent Radicalization." Terrorism and Political Violence 24(1):1-21.

http://dx.doi.org/10.1080/09546553.2011.594923

Beutel, Alejandro.J. 2007. "Radicalization and Homegrown Terrorism in Western Muslim Comunities: Lessons Learned for America." Vol.

Buijs, Frank J, Froukje Demant and Atef Hamdy. 2006. "Home Grown Warriors. Radical and Democratic Muslims in the Netherlands." Amsterdam: Amsterdam University Press.

Calvert, John. 2010. Sayyid Qutb and the Origins of Radical Islamism. New York: Columbia University Press.

Change Institute. 2008. "Studies into Violent Radicalization; Lot 2. The Beliefs Ideologies and Narratives." Vol. London: Change Institute.

Crawford, Carly. 2007. "Youth Form Radical Creche." in Herald Sun.

Defence, Department of. 2010, "Dictionary of Military Terms ", USA. (http://www.dtic.mil/doctrine/dod_dictionary/?zoom_query=ra dical\&zoom_sort=0\&zoom_per_page=10\&zoom_and=1).

Department of Foreigh Affairs and Trade (DFAT). 2004, "Transnational Terrorism: The Threat to Australia". Retrieved 14/03/2011, (http://www.dfat.gov.au/publications/terrorism/ is2.html).

European Commission. 2006. "Terrorist Recruitment: A Commission's Communication Addressing the Factors Contributing to Violent Radicalisation'." Vol.: MEMO/05/329.

Hassan, Riaz. 2008. Inside Muslim Minds. Melbourne: Melbourne University Press.

Horgan, John. 2005. The Psychology of Terrorism. New York: Taylor \& Francis Group. http://dx.doi.org/10.4324/9780203496961

Mandel, David R. . in press. "Radicalization: What Does It Mean?" in Indigenous Terrorism: Understanding and Addressing the Root Causes of Radicalisation among Group with an Immigrant Heritage in Europe, edited by T. P. A. Speckhard. Amsterdam:: IOS Press.

Mullins, Sam. 2011. "Islamist Terrorism and Australia: An Empirical Examination of the "Home-Grown" Threat." Terrorism and Political Violence 23(2):254-85. d http://dx.doi.org/10.1080/09546553.2010.535717

Murshed, S. Iftikhar. 2011. "Memories of Mardin." in International The News E-Paper.

Nasser-Eddine, M., B. Garnham, K. Agostino and G. Caluya. 2011. "Countering Violent Extremism (Cve) Literature Review." Vol.: Defence Science and Techonolgy Organisation (DSTO).

Neumann, Peter R, Brooke Rogers, Rogelio Alonso and Luis Martinez. 2007. "Recruitment and Mobilisation for the Islamist Militant Movement in Europe." ICSR.

Pape, Robert A. 2006. Dying to Win: The Strategic Logic of Suicide Terrorism: Random House.

Parkinson, Tony. 2002. "'Bin Laden' Voices New Threat to Australia." in The Age.

Petter, NESSER. 2004. "Jihad in Europe-a Survey of the Motivations for Sunni Islamist Terrorism in Post-Millennium Europe." FFI Rapport, Norwegian Defence Research Establishment, Norway:1-101.

Porter, Louise .E. and Mark R. Kebbell. 2010. "Radicalization in Australia: Examining Australia's Convicted Terrorists." Psychiatry, Psychology and Law.

Qutb, Sayed. 1964. Milestones. Birmingham, England: Maktabah Bookseller and Publishers.

Ramakrishna, Kumar. 2005. "Delegitimizing Global Jihadi Ideology in Southeast Asia." Contemporary Southeast Asia 27(3):34369.

http://dx.doi.org/10.1355/CS27-3A

2007, June 27. Radicalization of Global Islamist TerroristsCongress. 
Schwartz, Benjamin E. 2007. "America's Struggle against the Wahhabi/Neo-Salafi Movement." Orbis 51(1):107-28. http://dx.doi.org/10.1016/j.orbis.2006.10.012

Silber, Mitchell D. and Arvin Bhatt. 2007. "Radicalisation in the West: The Homegrown Threat." Vol.: The New York City Police Department.

Tobin, Mark. 2007. "Keelty Sceptical of Radical Muslims Report." PM (2 July, 2007). Retrieved: 22/02/13 (http://www.abc.net.au/ $\mathrm{pm} /$ content/2007/s1967949.htm).

Veldhuis, Tinka and Jorgen Staun. 2009. "Islamist Radicalisation: A Root Cause Model." Vol.: Netherlands Institute of International Relations Clingendael.
Woodlock, Rachel and Zachary Russell. 2008. "Perceptions of Extremism among Muslims in Australia." Paper presented at the Radicalistion crossing borders: New directions in Islamist and Jihadist political, intellectual and theological thought and practice conference, Melbourne, Vic.

Zammit, Andrew. 2011. "Who Becomes a Jihadist in Australia? A Comparative Analysis." Paper presented at the Understanding Terrorism from an Australian Perspective: radicalisation, de-radicalisation and counter radicalisation, Monash University.

Received on 19-03-2013

Accepted on 19-04-2013

Published on 06-05-2013

DOI: http://dx.doi.org/10.6000/1929-4409.2013.02.18

(c) 2013 Rahimullah et al.; Licensee Lifescience Global.

This is an open access article licensed under the terms of the Creative Commons Attribution Non-Commercial License (http://creativecommons.org/licenses/by-nc/3.0/) which permits unrestricted, non-commercial use, distribution and reproduction in any medium, provided the work is properly cited. 